\title{
Chemical Analysis of Hibiscus Rosa Sinenses-L
}

\author{
Bhawna Pandey ${ }^{1}$, S. K. Nigam ${ }^{2}$, S. S. Paihar ${ }^{1}$, Arvind Prasad Dwivedi \\ ${ }^{1}$ Department of Chemistry, Govt. Girls P. G. College, Rewa-486001 (M.P.) India \\ ${ }^{2}$ Govt. College Rampur Naikin, District Sidhi (M.P.) India \\ ${ }^{3}$ Department of Chemistry, Govt. Sanjay Gandhi Smrati Auto., P.G., College Sidhi M.P
}

*Corresponding Author: Bhawna Pandey, Department of Chemistry, Govt. Girls P. G. College, Rewa486001 (M.P.) India

\begin{abstract}
The chemical analysis of bio-sap of medicinal plants Hibiscus Rosa Sinenses-L (HRS) of malvaceae family have been performed chromatographically and documented. The work is restricted to the identification of pigments, and free amino acids. Various physical parameters related to analysis were determined. Electrophoretic method was employed to measure the relative motion of ions of amino acids. The fluorescent and UV spectroscopic methods were used for the active ingredient's analysis.
\end{abstract}

Keywords: Identification, ingredients, diffusion, relative mobility, extraction.

\section{INTRODUCTION}

Hibiscus a genus of flowering plants in malvaceae family contains 100 species that are native to warm grown in subtropical and tropical regions throughout India. It includes both woody shrubs and small trees. The flowers are large and of red and white colours. It is typically found almost everywhere. The red Hibiscus is the flower of the Hindu goddess Kali in Bengal India and offered goddess and Lord Ganesha in Hindu worship.

It has a long history as for health benefits are concerned, its tea is popular lowers blood pressure, decrease the concentration of LDL cholesterol. It is used as hair oil, paste, shampoo plus conditions, cosmetic skin care, anti-solar agent, notably in reduction of triglycerides and shows as anti-oxidant effect. ${ }^{2}$ Further studies are needed to demonstrate clinical significance. The suitable analytical procedure for the analysis ${ }^{3}$ of phytoconstituents such as chlorophylls, amino acids, lignans is of technical importance. In present investigation, we report here chromatographic fluorimetric, electrophoretic and other physical methods that provide good results of closely related constituents in different varieties of HRS medicinal plants. The various aspects of the analysis have been described.

\section{EXPERIMENTAL}

All the chemicals used in the study were of analytical grade. The solvents employed were distilled and their identities confirmed with the authentic standard methods. The biomass as an, electrolyte was isolated after performing various primary processes such as plucking, crushing and extraction of leaves from HRS medicinal plants collected as pooled samples.

The maximum content of phytoconstituents of $\mathrm{HRS}_{1}, \mathrm{HRS}_{2}$, and $\mathrm{HRS}_{3}$ was obtained by extracting with methanol separately. The extracts were filtered, dried under vacuum and made up to $1 \mathrm{ml}$ with $\mathrm{CH}_{3} \mathrm{OH}$ prior to chromatographic analysis. ${ }^{4,5}$ The ascending paper chromatography was performed for measuring $R_{f}$ values of the samples under a flow of nitrogen gas at experimental conditions of temperature and relative humidity. Several others analytical techniques ${ }^{6,7}$ involving fluorimetry, ${ }^{8} \mathrm{UV}$ spectrometry ${ }^{9}$, electrophoresis etc. have been described for the determination of lignans and other compounds ${ }^{10}$ of the system. The $\mathrm{pH}$, conductivity of biomass of medicinal plants have been digitally measured by $\mathrm{pH}$ and conductivity meter while the number of cells in sap is counted by research microscope. ${ }^{11}$

\section{RESULTS AND DISCUSSION}

The natural chlorophyll-b and chlorophyll-a along with xanthophyll and carotenes in two yellow and two green pigments were calculated from the extracts of the $\mathrm{HRS}_{1}, \mathrm{HRS}_{2}$, and $\mathrm{HRS}_{3}$. The results of $\mathrm{R}_{\mathrm{f}}$ 
values of three determinations obtained by ascending paper chromatography analysis, were comparable with those of $\mathrm{R}_{\mathrm{f}}$ reference values (Table 1). The chloroplast has been observed accompanying electron flow and formation of ATP during photic excitation (Phytosynthesis). The energy of photic excitation is converted into ATP and reduction of NADP to NADPH and $\mathrm{H}^{+}$. Swelling and shrinking of chloroplast have been observed during photosynthesis. That is why; $\mathrm{HRS}_{3}$ possesses much higher value in comparison to $\mathrm{HRS}_{2}$ and $\mathrm{HRS}_{1}$ respectively. The nine amino acids were detected chromatographically from the extracts of the samples of HRS and their $\mathrm{R}_{\mathrm{f}}$ values are recorded in (Table 2 ). The $R_{f}$ values facilitated the identification by ninhydrin locating reagent.

The $R_{f}$ values of phyllanthin and hypophyllanthin from other closely related lignans were also determined as 0.17 and 0.20 respectively. The chromatographic separation was also carried out for carbohydrates (Table 3). The fluorescent analysis of the samples under investigation using UV light gave different colors were also analyzed. Various physical parameters such as $\mathrm{pH}$, conductivity, density and surface tension have also been determined (Table 4).

The relative mobility of amino acids (known and unknown) was studied in samples of variants HRS by electrophoretic method at $\mathrm{pH} 1.81$ and 5.2 respectively (Table 5 and 6). It was observed that electrophoresis at low voltage is not usually used/ permissible to separate low molecular weight amino acids because of diffusion but it is easier to illustrate the relationship between charge and $\mathrm{pH}$ with amino acids than with proteins or other macromolecules. With exception of other amino acids was not detected in any variants of HRS analyzed.

Table1. Identification of pigments for Hibiscus Rosa Sinenses-L., by chromatographic method

\begin{tabular}{|l|l|l|c|c|c|}
\hline S. No. & \multirow{2}{*}{ Pigments } & \multirow{2}{*}{ Colour } & \multicolumn{3}{|c|}{$\mathbf{R}_{\mathbf{f}}$ values } \\
\cline { 4 - 6 } & & & $\mathbf{H R S}_{\mathbf{1}}$ & $\mathbf{H R S}_{\mathbf{2}}$ & $\mathbf{H R S}_{\mathbf{3}}$ \\
\hline 1. & Chlorophyll-b & Green & 0.26 & 0.33 & 0.37 \\
\hline 2. & Chlorophyll-a & Blue green & 0.35 & 0.29 & 0.30 \\
\hline 3. & Xanthophyll & Yellow brown & 0.59 & 0.64 & 0.75 \\
\hline 4. & Carotene & Yellow & 0.85 & 0.87 & 0.91 \\
\hline
\end{tabular}

Table2. Chromatographic separation of Amino acids

\begin{tabular}{|c|c|c|c|c|c|c|}
\hline \multirow{2}{*}{$\begin{array}{l}\text { S. } \\
\text { No. }\end{array}$} & \multirow[t]{2}{*}{ Pigments } & \multirow{2}{*}{ Colour } & \multicolumn{3}{|c|}{$\mathbf{R}_{\mathrm{f}}$ values } & \multirow{2}{*}{$\begin{array}{l}\text { References } \\
\text { values }\end{array}$} \\
\hline & & & HRS $_{1}$ & $\mathrm{HRS}_{2}$ & $\mathrm{HRS}_{3}$ & \\
\hline 1. & $\begin{array}{l}\text { Alanine } \\
(\alpha \text {-amino propionic acid) }\end{array}$ & $\begin{array}{l}\text { Light brown } \\
\text { purple }\end{array}$ & 0.35 & 0.39 & 0.41 & 0.42 \\
\hline 2. & $\begin{array}{l}\text { Aspartic acid } \\
(\alpha \text {-amino succinic acid })\end{array}$ & Blue & 0.11 & 0.15 & 0.13 & 0.19 \\
\hline 3. & $\begin{array}{l}\text { Glycine (amino acetic } \\
\text { acid) }\end{array}$ & $\begin{array}{l}\text { Deep bluish } \\
\text { purple }\end{array}$ & 0.49 & 0.52 & 0.47 & 0.58 \\
\hline 4. & $\begin{array}{l}\text { Leucine } \\
\text { ( } \alpha \text {-amino isocaproic acid) }\end{array}$ & $\begin{array}{l}\text { Light purple } \\
\text { bluish }\end{array}$ & 0.84 & 0.79 & 0.84 & 0.88 \\
\hline 5. & $\begin{array}{l}\text { Proline } \\
(\alpha \text {-carboxylic acid })\end{array}$ & $\begin{array}{l}\text { Yellowish } \\
\text { violet }\end{array}$ & 0.77 & 0.89 & 0.78 & 0.94 \\
\hline 6. & Phenyl analine & Blue brown & 0.11 & - & 0.13 & 0.85 \\
\hline 7. & $\begin{array}{l}\text { Tyrosine } \\
(\alpha \text {-amino- } \beta \text {-cp-hydroxy } \\
\text { phenyl) propionic acid }\end{array}$ & $\begin{array}{l}\text { Purple } \\
\text { yellowish } \\
\text { violet }\end{array}$ & 0.76 & 0.77 & 0.75 & 0.82 \\
\hline 8. & $\begin{array}{l}\text { Threonine } \\
(\delta \text {-amino-- } \beta \text {-hydroxyl-n- } \\
\text { butyric acid }\end{array}$ & Blue light & 0.71 & 0.78 & 0.79 & 0.82 \\
\hline 9. & Valine & Blue & 0.66 & 0.69 & 0.68 & 0.73 \\
\hline
\end{tabular}

Table3. Chemical analysis of carbohydrates by ascending paper chromatographic method

\begin{tabular}{|l|l|c|c|c|c|}
\hline \multirow{2}{*}{ S. No. } & \multirow{2}{*}{ Sugar } & \multicolumn{3}{|c|}{$\mathbf{R}_{\mathbf{f}}$ values } & References \\
\cline { 3 - 5 } & & $\mathbf{H R S}_{\mathbf{1}}$ & $\mathbf{H R S}_{\mathbf{2}}$ & HRS $_{\mathbf{3}}$ & 0.21 \\
\hline 1. & D-fructose & 0.18 & 0.20 & 0.17 & 0.70 \\
\hline 2. & D-Lactose & 0.71 & 0.72 & 0.69 & 0.10 \\
\hline 3. & D-glucose & 0.098 & 0.091 & 0.083 & 0.20 \\
\hline 4. & L-Sorbose & 0.22 & 0.19 & 0.23 & 0.09 \\
\hline 5. & R-affinose & 0.088 & 0.093 & 0.07 & 0.17 \\
\hline 6. & D-galactose & 0.15 & 0.18 & 0.16 & \\
\hline
\end{tabular}


Table4. Physical parameters for medicinal plant Hibiscus Sinenses-L

\begin{tabular}{|l|l|c|c|c|c|}
\hline S. No. & System & $\mathbf{p H}$ & $\begin{array}{c}\text { Density } \\
\text { Gram/cm }\end{array}$ & $\begin{array}{c}\text { Surface tension } \\
\text { dynes/cm }\end{array}$ & $\begin{array}{c}\text { Conductivity } \\
\text { Siemen(s) }\end{array}$ \\
\hline 1. & $\mathrm{HRS}_{1}$ & 5.51 & 0.891 & 41.1 & $2.73 \times 10^{-3}$ \\
\hline 2. & $\mathrm{HRS}_{2}$ & 5.48 & 0.896 & 41.8 & $2.69 \times 10^{-3}$ \\
\hline 3. & $\mathrm{HRS}_{3}$ & 5.47 & 0.906 & 40.8 & $2.71 \times 10^{-3}$ \\
\hline
\end{tabular}

Table5. Relative Mobilities of known Amino acids (Electrophoretic method)

\begin{tabular}{|l|c|c|c|}
\hline \multirow{2}{*}{ S. No. } & Compound & \multicolumn{2}{|c|}{ Relative mobility in electrode (mm) } \\
\cline { 3 - 4 } & & Ia & 2b \\
\hline 1. & Alanine & -100 & -100 \\
\hline 2. & Glycine & -116 & - \\
\hline 3. & Leucine & -77 & -73 \\
\hline 4. & Threonine & -75 & -78 \\
\hline
\end{tabular}

a. $2.5 \%(\mathrm{~W} / \mathrm{V}) \mathrm{HCOOH}-7.8(\mathrm{~W} / \mathrm{V}) \mathrm{CH}_{3} \mathrm{COOH}$, Mobility relative to alanine $\mathrm{pH}$ 1.87,

$100 \mathrm{~V} / \mathrm{Cms}$;

b. $2 \%(\mathrm{~W} / \mathrm{V}) \mathrm{HCOOH}-20 \%(\mathrm{~W} / \mathrm{V}) \mathrm{CH}_{3} \mathrm{COOH}-0.4 \mathrm{~mm} \mathrm{Cd}$ acetate $\mathrm{pH} 1.84$,

$100 \mathrm{~V} / \mathrm{Cm}$, Mobility relative to alanine.

Table6. Relative Mobilities of unknown (observed values) of Amino acid at pH 5.2 (Electrophoretic method)

\begin{tabular}{|l|c|c|c|}
\hline \multirow{2}{*}{ S. No. } & Compound & \multicolumn{2}{|c|}{ Relative mobility in electrode (mm) } \\
\cline { 3 - 4 } & & Ia & 2b \\
\hline 1. & Alanine & -102 & -102 \\
\hline 2. & Glycine & -116 & -78 \\
\hline 3. & Leucine & -79 & -78 \\
\hline 4. & Threonine & -78 & - \\
\hline
\end{tabular}

\section{CONCLUSION}

The analysis of lignans and pigments by modern techniques would be very helpful for others medicinal plants too. The study may be extended for use an anti-oxidant, and in practicing traditional system of generic medicines, as-well-as cosmetics and detergents industries.

\section{REFERENCES}

[1] Harvey, A.L. Drug Discovery Today, 2009, 13: (19-20), 849-901.

[2] Khatoon, S., Rai, V., Rawat, A.K.S., and Mehrotra, S., J. Ethnophamac, 2006, 104: 79-86.

[3] Anupama, P., Ayurveda Herb. 2013, 1: 6.

[4] Tripathi, Arvind, K., Verma, Ram K., Gupta, Anil K., Madan, M., and Suman, Khanuja P.S., Phytochem. Anal., 2006, 17, 394-397.

[5] Frey, H.P. and Zieloff, K. Qualitative and Quantitative Chromatography, Grund lagen and Praxis, VCO, 1993.

[6] Wang, C.Y., and Lee, S.S., Phytochem. Anal., 2005, 16: 120-126

[7] Shrivastava, S., Gupta, M.M., Verma, R.K., and Kumar, S., J. Assoc. off Anal Chem. (Int.), 2000, 83: 1484-1488.

[8] Lakowiczj, J.R., Principles of Fluorescence spectroscopy, Kluwer Academic Plenum Publishers, 1999.

[9] Vogel, I. Elementary, practical organic chemistry, Pearson, Education Publication, 2010.

[10] Bunkar, Alka Rani, Int. J. Chem. Studies, 2017, 5(1): 09-11.

Citation: B. Pandey, "Chemical Analysis of Hibiscus Rosa Sinenses-L", International Journal of Advanced Research in Chemical Science (IJARCS), vol. 5, no. 2, pp. 6-8, 2018. http://dx.doi.org/10.20431/2349. 0403.0502002

Copyright: (C) 2018 Authors. This is an open-access article distributed under the terms of the Creative Commons Attribution License, which permits unrestricted use, distribution, and reproduction in any medium, provided the original author and source are credited. 